\title{
LEISURE TIME FOR SECONDARY SCHOOL STUDENTS
}

\author{
Dr. Besa Havziu, State University of Tetova, Republic of Macedonia \\ E-mail: besah_80@yahoo.com \\ Dr. Teuta Ramadani Rasimi, State University of Tetova, Republic of Macedonia \\ E-mail: t.rasimi@gmail.com
}

Received: May, 14.2015.

Accepted: June, 01.2015.

Original Article

UDK 379.8-053.6(497.7)

\begin{abstract}
Today, in education prevails the paradigm that is geared towards the complete and varied development of a person. This implies the development of the students ability for self-determination towards various other perspective offered by contemporary social residence. Meanwhile in the time of adolescence, the youth experience serious crises regarding their identity, in which the free time and the activities during the free time can be positively used with a cause to be interrupted unconstructive and chaotic use of the free time by the youth. In this thesis are being analyzed the contents and the ways with what the secondary school students in the Republic of Macedonia fulfill their free time outside the school, specifically there will be an examination about the gender differences i.e. the amount and manner of spending their free time. In the approach to the study of the problem of research, we decided to apply: inductive method, deductive method and the method of comparison.

Keywords: Leisure time, Student, Extracurricular activities, Culture, Activities structured, Unstructured activities, Gender differences and the amount of free time.
\end{abstract}

\section{INTRODUCTION}

The modern society has drawn with itself less free time to spend it qualitatively. According to the analysis of the different conceptions of leisure time we can say that:

- Leisure time is socially conditioned phenomenon, as a class and historical, is conditioned by economic, cultural, scientific and technological development, etc.

- Presents an integrated part of human life, wherein people through leisure activities develops, builds, actually it develops their work and their individual essence (being).

- Is stained with different values, which are expressed through numerous leisure activities.

- Represents (relative) freedom in se-

Corresponding Author

Dr. Besa Havziu, State University of Tetova, Republic of Macedonia, E-mail: besah_80@yahoo.com lecting these activities (Kačavenda Radić N.,1989).

It means that free time provides an opportunity to students' personality to form, implement, and socialize, this time actually enables to the young person to get closer to the real world, respectively the world that surrounds it. How young people spend their leisure time, it is one of the most important designing that actually determines their way of living. For the young there is almost no more important time than their leisure time. Precisely at the moment the pressure from the families, the burden of school and the family responsibilities will cease, then this remaining time is the time where young people feel at the same time allocated for it. To avoid various deviant behaviors among young people, we should be very careful, as to how to prepare them to face different social changes (challenges), how to organize and build a culture of proper buildup and spending leisure time. Leisure time is a social phenomenon that requires a thorough approach in all spheres of life. It is the time when we recognize the man as homo univerzalis, homo ludens and homo autocreator (Schaff, A., 1989).

Nowadays leisure time exists as a social phenomenon and is a composed part of every person's life. The problem that exists is how to prevent unconstructive use of leisure time, which is a component part of everyday life for young people. It is a time in which the student can live in harmony with its individual nature, in which can affirm and develop its properties. It is an important device for rest, recreation, turning away from everyday worries and burdens, an important factor for the development of personality (Баракоска, А., 2005).

If leisure time is a time of certain activities, then the question arises: What are these major activities that affect the formation of the culture of leisure time?

So the main problem is with what kind 
of activities is fulfilled that time. Leisure time can be fulfilled in a constructive and socially acceptable way and constructive unacceptable harmful use of leisure time. Nowadays under the blows of the commercial entertainment industry young people are more inclined towards constructive use of leisure time (Костова et al., 2005).

Thereby its very important and the society itself to show proper care not only for providing greater productivity of labor, but also for the use of leisure time, why cannot be all the same "if the individual their leisure time is spending in a way that degrades or in a rich and developed, respectively he is able in their activities to bring real cultural content and meet those needs and work experience that the job did not come to the fore" (Дамјановски, A., 1969).

On the other hand the author R. Popova says:"Fact is that nowadays, the cultural needs of the person mark a drastically rise, and in society exist various sources of their satisfaction, starting from kitsch and trash, until real art (music, art, film, literature) with high qualitative and artistic values"(Popova, R., 1999).

Here actually fall mass media, TV, radio, social network (Facebook, YouTube, etc.), then printing, etc., that provide quality programs among which there are various educational programs. But the question is how they are "consumed" by the youth. Therefore, studies conducted worldwide have shown that "Quality programs that are less listened and watched, but, therefore again, where there are more TV channels and several radio stations, artistically the weakest programs attract the largest number of viewers" (Langran, P., 1976).

These programs do not actually contribute to the development of culture for constructive use of leisure time by youth, and to not mention the various social networks that despite the positive aspects, which in moderation develop, there are many negative consequences that deeply affect the general development of the young person. In this context the author A. Damjanovski says: "To liberate youth to use their free time in a manner worthy of man" (Дамјановски, А., 1969).

In the approach towards the examination of this phenomenon is necessary to achieve the required consistency and verification of the scientific research procedures collection and processing of the empirical data Analysis, interpretation and explanation of the results, extraction of the adequate conclusions will be based upon the application of adequate methodological procedures that will secure the stated realtions, according to the nature of the researched phenomenon. Notably the phenomenon of free time among young people represents distinctively complicated appearance from the perspective of the phenomenology and etiological factors which serve its appearance and existence. Because insufficient theoretical and empirical knowledge of the problem, we believe it is beneficial for our society to be investigated the content with which the secondary school students fill their free time outside of school. In the project will be analyzed the quantity and usage patterns of leisure time secondary school students in Republic of Macedonia. For operationalization of the purpose of the research we put one general and three auxiliary hypotheses.

The general hypothesis: The pleasure with the way spending leisure time in secondary school students is aimed at establishing a Culture of the usage of the leisure time.

Auxiliary hypotheses:

1. High school students female and male gender are differentiated by the amount, manner and degree of overall satisfaction with the passage of leisure time.

2. High school students female and male gender are differentiated by the proportion of organized and unorganized forms of free leisure time activities.

3. High school students female and male gender are differentiated by the degree of use of the principle of free choice in the leisure activities.

\section{MATERIALS AND METHODS}

In our research participated all together 100 high schools students in Macedonia, from whom 52 were males and 48 females. We used a combination of qualitative and quantitative approach, were the qualitative approach was conducted through observation using the diary as an instrument for collecting the data, whilst the results where analyzed with the technique called interim, were we code the answer, indexed them and group it to an appropriate category.

\section{RESULTS}

In the interest of the labor below we will present the obtained results through observations about gender differences in spending leisure time among our respondents (secondary school students). Firstly, we were inter- 
ested whether there are differences between the genders in terms of the amount of leisure time. The nonparametric Mann-Whitney test indicates statistically significant difference $(Z=-2.671, p<0,01)$ between the two genders in the amount of free time, based on an assessment of the interrogated. Male respondents obviously have more free time compared to their peers, which is good reflected in the attached cross table.

Table 1. Amount of free time (how do the surveyed high school males and females spend their free time)

\begin{tabular}{llrrr}
\hline \multicolumn{4}{c}{ How much free time did you have today? } & \multirow{2}{*}{ Total } \\
\hline \multirow{2}{*}{1.0 or less hours } & F & M & \\
\cline { 2 - 5 } & Received scores & 5 & 1 & 6 \\
\cline { 2 - 5 } 2.30 hours & Anticipated scores & 2.9 & 3.1 & 6.0 \\
\cline { 2 - 5 } & Received scores & 28 & 22 & 50 \\
\cline { 2 - 5 } & Anticipated scores & 24.0 & 26.0 & 50.0 \\
\hline \multirow{2}{*}{4 hours } & Received scores & 14 & 27 & 41 \\
\cline { 2 - 5 } & Anticipated scores & 19.7 & 21.3 & 41.0 \\
\hline \multirow{2}{*}{5 and more hours } & Received scores & 1 & 2 & 3 \\
\cline { 2 - 5 } & Anticipated scores & 1.4 & 1.6 & 3.0 \\
\hline \multirow{3}{*}{ Total } & Received scores & 48 & 52 & 100 \\
\cline { 2 - 5 } & Anticipated scores & 48.0 & 52.0 & \multirow{2}{*}{100.} \\
\hline
\end{tabular}

The data related to who do the free time is spend with are tested with the test of the significance of differences between the arithmetic means of the independent samples (t-test), whereas the existing stereotype that girls most of their time spend within the circle of their family is partly confirmed by the received results. If they spend their free time alone, there are no statistical proofs for a difference between the two genders $(\mathrm{t}=1,033 \mathrm{df}=98$, $p=0.304$ ), but if the free time is spent together with the family members, then the difference is statistically significant towards the females $(\mathrm{t}=2.107, \mathrm{df}=98, \mathrm{p}<0.05)$. On the other hand, boys prefer to spend their free time with their friends, away from the domestic atmosphere $(\mathrm{t}=3.300, \mathrm{df}=98, \mathrm{p}<0.01)$, which can be better seen on the attached Table 2.

Table 2. How do the surveyed high school males and female spend their free (with whom)

\begin{tabular}{lccc}
\hline \multicolumn{2}{l}{ Where did you spend most of your free time? } & $\mathrm{N}$ & $\mathrm{M}$ \\
\hline $\begin{array}{l}\text { I spent my free time at home (how } \\
\text { many times of total 10 days) }\end{array}$ & $\mathrm{F}$ & 48 & 3.73 \\
\cline { 2 - 4 } & $\mathrm{M}$ & 52 & 1.58 \\
\hline $\begin{array}{l}\text { I spent my free time outside, in pen } \\
\text { premises - in the city or park (how } \\
\text { many times of total 10 days) }\end{array}$ & $\mathrm{F}$ & 48 & 3.08 \\
\hline $\begin{array}{l}\text { I spent my free time in open premises } \\
\text { - at friends, bars etc. (how many times } \\
\text { of total 10 days) }\end{array}$ & $\mathrm{F}$ & 52 & 3.27 \\
\hline
\end{tabular}

For additional knowledge about the mode (manner) of the spending of free time, the surveyed were asked to identify where they spend their free time predominantly. The results of the junctions of the variables firstly prove the just presented data that girls spend their free time mostly in domestic atmosphere $(\mathrm{t}=12.360, \mathrm{df}=98, \mathrm{p}<0.00)$. There are not found differences between the two genders regarding the spending of free time outside, in open air premises $(t=0.701, d f=98, p=0.485)$, but there exists a statistically significant difference by the males when the free time is spent outside the house in closed premises, bars, betting shops, night entertainments etc $\mathrm{t}=5,963, \mathrm{df}=98, \mathrm{p}<0.000)$, which is seen in the following Table 3 .

Table 3. How do the surveyed high school males and females spend their free (where, in which premises)

\begin{tabular}{lccc}
\hline Who did you spent your free time with? & & $\mathrm{N}$ & $\mathrm{M}$ \\
\hline \multirow{2}{*}{$\begin{array}{l}\text { I spent my free time alone (how many } \\
\text { times of total 10 days) }\end{array}$} & $\mathrm{F}$ & 48 & 2.00 \\
\cline { 2 - 4 } & $\mathrm{M}$ & 52 & 1.71 \\
\hline $\begin{array}{l}\text { I spent my free time with my friend (how } \\
\text { many times of total 10 days) }\end{array}$ & $\mathrm{F}$ & 48 & 4.06 \\
\cline { 2 - 4 } & $\mathrm{M}$ & 52 & 5.27 \\
\hline $\begin{array}{l}\text { I spent my free time with my parents } \\
\text { (how many times of total 10 days) }\end{array}$ & $\mathrm{F}$ & 48 & 3.92 \\
\cline { 2 - 4 } & $\mathrm{M}$ & 52 & 3.06
\end{tabular}

We also surveyed the gender differences at the extent of the total satisfaction from the own free time. Non-parametric Mann Whitney test is statistically significant $(\mathrm{z}=3.056$, $\mathrm{p}<0.01)$ which means that there exists a difference between the two genders according to this variable. The qualitative insight in the crossed table indicates clearly that the surveyed males declare more frequently that are satisfied with their free time.

Table 4. Satisfaction from the manner of how the surveyed high school males and females spend their free time

\begin{tabular}{|c|c|c|c|c|c|}
\hline \multicolumn{6}{|c|}{$\begin{array}{l}\text { How much are you satisfied from the way you have spent } \\
\text { your free time? }\end{array}$} \\
\hline & & & $\mathrm{F}$ & $\mathrm{M}$ & $\mathrm{N}$ \\
\hline \multirow{2}{*}{$\begin{array}{l}\text { Not } \\
\text { satisfied at } \\
\text { all from }\end{array}$} & \multirow{2}{*}{$\begin{array}{l}10-16 \\
\text { (In a } 10 \\
\text { day) }\end{array}$} & $\begin{array}{l}\text { Received } \\
\text { scores }\end{array}$ & 1 & 0 & 1 \\
\hline & & $\begin{array}{l}\text { Anticipated } \\
\text { scores }\end{array}$ & 0.5 & 0.5 & 1.0 \\
\hline \multirow{2}{*}{$\begin{array}{l}\text { Partially } \\
\text { satisfied } \\
\text { from }\end{array}$} & \multirow{2}{*}{$\begin{array}{l}17-23 \\
\text { (In a } 10 \\
\text { day) }\end{array}$} & $\begin{array}{l}\text { Received } \\
\text { scores }\end{array}$ & 31 & 19 & 50 \\
\hline & & $\begin{array}{l}\text { Anticipated } \\
\text { scores }\end{array}$ & 24.0 & 26.0 & 50 \\
\hline \multirow{2}{*}{$\begin{array}{l}\text { Very } \\
\text { satisfied } \\
\text { from }\end{array}$} & \multirow{2}{*}{$\begin{array}{l}24-30 \\
\text { (In a } 10 \\
\text { day) }\end{array}$} & $\begin{array}{l}\text { Received } \\
\text { scores }\end{array}$ & 16 & 33 & 49 \\
\hline & & $\begin{array}{l}\text { Anticipated } \\
\text { scores }\end{array}$ & 23.5 & 25.5 & 49 \\
\hline Total & & $\begin{array}{l}\text { Received } \\
\text { scores }\end{array}$ & 48 & 52 & 100 \\
\hline
\end{tabular}

According to the above elaborated results through which are examined the amount, manner and satisfaction from their free time of the high school pupils, is also proved the first auxiliary hypothesis: H1-Female and male high school pupils differ among themselves according to the amount, manner and the degree of total satisfaction of their free time. 
The following section of the crossing between the variables is about the testing of gender differences according to the degree of organization (structuring) of the free time. From the received results be categorically claimed that there exist differences between the two genders. The received differences between the arithmetical means (t-test) are not relevant, but the fact that the values are near the limits for statistical relevance suggests that such association should not be a priory excluded. In our case, concretely, there exists a tendency that males prefer more the practice of the unorganized forms to spend their free time $(\mathrm{t}=1.674, \mathrm{df}=98, \mathrm{p}=0.097)$, while females prefer organized forms $(\mathrm{t}=1.597, \mathrm{df}=98$, $\mathrm{p}=0.113$ ).

Table 5. Gender differences according to the degree of organization (structuring) of free time

\begin{tabular}{lllll}
\hline $\begin{array}{l}\text { Were your free activities imposed by } \\
\text { the parents, friends, mass culture, or } \\
\text { were they your own choice? }\end{array}$ & \multicolumn{2}{l}{$\mathrm{N}$} & $\mathrm{M}$ \\
\hline They were my choice! & $\mathrm{F}$ & 48 & 5.48 \\
\cline { 2 - 5 } & $\mathrm{M}$ & 52 & 6.06 \\
\hline They were imposed to me! & $\mathrm{F}$ & 48 & 4.62 \\
\cline { 2 - 5 } & $\mathrm{M}$ & 52 & 3.90 \\
\hline
\end{tabular}

From here our second auxiliary hypothesis: H2-,,Female and male high school pupils differ among themselves according to the ratio of organized and unorganized forms of activities in free time,, is partially proved.

We were also interested about the representation of the principle of free choice among young people when choosing the free activities. The crossing of these data with the gender affiliation indicates that this principle is highly more present among males. With other words, males declare significantly more than girls that they choose their free activities according to their own interests $(t=2.029$, $\mathrm{df}=98, \mathrm{p}<0.05$ ). Analogous, among females is more present the occurrence of imposition by other people (parents, school) when choosing free activities $(\mathrm{t}=2.536, \mathrm{df}=98, \mathrm{p}<0.05)$.

Table 6. Representation of the principle of free choice among the young people when choosing free activities

\begin{tabular}{lcccc}
\hline $\begin{array}{l}\text { With which activities did you } \\
\text { fulfill your free time? }\end{array}$ & $\mathrm{N}$ & $\mathrm{M}$ & $\mathrm{SD}$ \\
\hline $\begin{array}{l}\text { Unorganized, } \\
\text { unstructured individual } \\
\text { and social activities }\end{array}$ & $\mathrm{M}$ & 52 & 5.46 & 1.260 \\
\cline { 2 - 5 } $\begin{array}{l}\text { Organized, structured } \\
\text { social and individual } \\
\text { activities }\end{array}$ & $\mathrm{F}$ & 48 & 5.04 & 1.856 \\
\cline { 2 - 5 } & $\mathrm{M}$ & 52 & 4.54 & 1.260 \\
\hline
\end{tabular}

According to the received results we can conclude that our third auxiliary hypothesis $\mathrm{H} 3$ is proved:

„Female and male high school pupils differ among themselves according to the degree they use the principle of free choice in free activities,

Besides the statistical processing of the results obtained through the registration in diary in duration of 10 days where each student had to take notes about what they do in their free time, the same results were also elaborated in qualitative (descriptive) manner. In addition, we will list only some of the obtained results related to the satisfaction, manner and compliance of free time.

From the total number of 100 high school pupils who were surveyed, we had more answers and notes about that both male and female pupils, spend their free time mostly in unstructured general activities, by claiming that they fulfill their free time with passive activities, which means they are prone to the unstructured way of spending their free time, but a great deal of the surveyed $40 \%$ who were included in various non-formal activities, as for example: the Respondent 5-I.S. who trains each week in the basketball club, or the Respondent $8-\mathrm{M}$. V. also from Tetovo who is a member in a humanitarian organization etc, indicate that for these pupils the free time activities are an important factor in the overall development of their personality, at the same time they showed a greater satisfaction about their free time, contrary to their peers who simply filled their free time with passive activities. Moreover, they already had a more positive regime of their free time, who spontaneously and partly in imposed manner, they contributed in the formation of the culture of the leisure usage by the youth.

From the above mentioned data and the obtained results, the commenting and confirmation of the auxiliary hypothesis, we can conclude that our general hypothesis is also proved:

"The satisfaction with the manner of the spending of free time of the high school pupils is in the function of the formation of the culture of leisure usage."

\section{DISCUSSIONS}

According to the theoretical basis and the attached results, is illustrated the fact that the organization of free time appears as an important factor for: the emancipation of the 
personality of young people, creates conditions for leisure, active recreation, opportunity for socialization and humanization, raises the self-esteem, with one word it has a great impact in the development of the personality, wherein to the youth are given more opportunities and choices for correct and constructive usage of the free time.

Based on the above we consider that in youth we need to develop authentic cultural, artistic, moral, aesthetic, physical and work values, skillfully selecting those negative and those providing inappropriate entertainment and escape from constructive use of leisure time. Starting from that the leisure time is the time that is available to the person of a young man, while deprived of obligations (school, family and social), we believe that this part of their everyday lives should be filled with organized activities, activities that offer an opportunity to overcome the passivity of the young man, but always respecting the principle of free choice.

\section{CONCLUSIONS}

The analysis of the theoretical debates on this problem as well as the empirical data that came in the research using the technique diary of activities of secondary school students, enabled us enlightenment of some aspects of the studied problem, at the same time have enabled and confirmed the general and both the of the auxiliary hypotheses ( $\mathrm{H} 1$ and $\mathrm{H} 2$ ), While in the same time partially was rejected the auxiliary hypothesis $\mathrm{H} 3$ which stated: High school female and male gender are differentiated by the ratio of organized and unorganized forms of free leisure. "The conclusions of this research should be upheld in order to further improvement and enrich the leisure time of young people organized and structured activities in order to prevent and avoid unwanted behaviors among youth Given that leisure time is the time that is available to the young person himself time deprived of obligations (school, family and social) we consider that this part of their everyday life should be filled with organized activities, activities that provide an opportunity to overcome the passivity of the young person and also influencing the formation of the culture of free time. Since the question arises: In which way we should lead the youth to use their free time and how certain factors affect?

Than we simply offer freedom in choosing activities, which in no way constitutes commitment or a sense of obligation but on the contrary it is a sense of fulfillment and inner freedom. But while young people decide their leisure time to spend on passive and disorganized manner, for example. conscious waste of time for no reason, unduly spending time in bars, clubs, restaurants, playing poker, or computer games, Then consumption of different narcotic substances, etc., then arises the need of choosing leisure time activities to lead in a positive direction, which will raise the awareness of young people. Because of this fact have high responsibility all educational and social institutions to commit towards offering a variety of organized activities, activities that provide opportunities for proper and mature development of values, feelings, attitudes, knowledge, skills and behaviors of young people because since the way of spending free time is left to the various individual negative factors it could negatively affect the taste and cultural use of leisure time therefore we should be very careful when it comes to the needs and opportunities of the youth in the fulfillment to his leisure time.

\section{ACKNOWLEDGMENTS}

This paper wouldn't have been compiled together without the moral and intellectual support of Prof.dr. Aneta Barakovska, to whom we express our infinite gratitude for her time and effort invested in us. Also we would like to thank the students of high schools that participated voluntarily in the research.

\section{Conflict of interests}

Authors declare no conflict of interest.

\section{REFERENCES}

Kačavenda Radić N. (1989). Slobodno vreme $i$ obrazovanje. Beograd: Zavod za udžbenike i nastavna sredstva. Beograd.

Langran, P. (1976). Uvod u permanentno obrazovanje, BIGZ: Beograd.

Popova, R. (1999). Општо образование, НИПГлобус: Скопје.

Schaff, A. (1989). Kamo vodi taj put. Globus, Zagreb.

Баракоска, А. (2005). Педагогија на слободното време, Доминант, Скопје.

Дамјановски, А. (1969). Функцијата и структурата на современото општо образование, Просветно дело: Скопје.

Костова, М., Баракоска, А., Маказлиева, Е. (2005). Педагогија, Просветно дело, Скопје. 
(IJCRSEE) International Journal of Cognitive Research in Science, Engineering and Education Vol. 3, No.1, 2015. 